\title{
NUMERICAL INVESTIGATION OF EFFECTS OF WORKING CONDITIONS ON PERFORMANCE OF PEM FUEL CELL
}

\author{
M. Ozdogan ${ }^{1, *}$, L. Namli ${ }^{1}$, A. Durmus ${ }^{1}$
}

\begin{abstract}
In this study, the effects of the working pressure and temperature on the performance of the PEM fuel cell were investigated numerically. Non-isothermal, steady-state and single-phase model was used to examine the behaviour of the proton exchange membrane (PEM) fuel cells in the three-dimensional condition. The threedimensional single-cell model has been developed within FLUENT 6.3 software by utilizing the PEMFC module. The results of polarization (voltage) variation curves and current density distribution were given and compared with each other. According to the results obtained, by keeping humidification and cell temperatures in equilibrium, the performance of the cell improves with the increasing cell temperature. In addition, the current density of the cell increases with the increasing operating pressure.
\end{abstract}

\section{Keywords: PEM Fuel Cell, Working Conditions, Three-Dimensional Modelling}

\section{INTRODUCTION}

Energy consumption in the world is increasing day by day. The share of renewable energy in the world's energy consumption is $9 \%$ (7\% hydraulic and $2 \%$ other renewable) [1]. Dissemination of fuel cells which is another renewable energy source is important for the security of energy supply and for a healthy environment. Fuel cells are electrochemical energy converters which convert the fuel directly into electricity without any burning process. There are many types of fuel cells based on types of electrode used. The proton exchange membrane fuel cells (PEMFC) are widely used in fuel cells due to its low working temperature, high power density, low pollution, quick start up and shutdown capability [2]. The performance of the PEMFC depends on many factors such as working condition, design and material parameters [3].

Güvenlioğlu and Stenger [4] modelled a PEMFC which is steady-state and two-dimensional. They assumed that distribution of temperature was homogenous. They investigated the effect of the channel geometry and the relative humidity of the reactants on the performance of the cell. They obtained higher current densities at the smaller flow length of channel and thickness of the bipolar plate. Kim et al. [5] compared two- and threedimensional models to examine the effect of two-dimensional modelling PEMFC. They found out similar result in each model but they got more accurate results from the three-dimensional model. Dadda et al. [6] developed a two-dimensional unsteady model to investigate heat and mass transfer at the PEMFC. They gave changes of distribution of temperature and water concentration with time as a result. Berning and Djilali [7] investigated the effects of temperature, pressure, the concentration of reactants, the thickness and the pore structure of the gas diffusion electrode and the thickness of the flow channel on the performance of PEMFC. Carcadea et al. [8] developed three-dimensional, steady-state and single-phase model in order to investigate the mass and charge transfer in a PEMFC. They modelled two types of PEM fuel cells which were conventional and interdigitated flow fields and compared fuel cell types each other. Lobato et al. [9] modelled PEMFC with three different types of flow channel design: 4-step serpentine, parallel and pin-type to investigate the effects of channel geometries. The results of the model in this study showed a similar performance at serpentine and pin-type flow channels. On the other hand, at the parallel type flow channel, the model results have shown low performance. Reffeira et al. [10] modelled the one-dimensional PEMFC which has two-phase flow. They compared the results obtained by the twophase flow model with those found by the single-phase flow model. Ahmadi et al. [11] investigated numerically and experimentally the influence of the operating pressure and gas diffusion layer geometrical configuration on the PEM fuel cell performance. Heidary et al. [12] investigated numerically the effect of temperature, pressure and saturation level on the cathode catalyst layer. According to their results, the cell performance increases with the This paper was recommended for publication in revised form by Tolga Taner 'Department of Mechanical Engineering, Ondokuz Mayıs University, Samsun, TURKEY *E-mail address: muhammet.ozdogan@omu.edu.tr Orcid id: 0000-0002-3523-6035, 0000-0001-9758-0889, 0000-0002-0281-365X Manuscript Received 30 May 2017, Accepted 31.July 2017 
increasing temperature and pressure. They found out that saturation level the most effective parameter on cell performance and the increasing saturation reduced the cell performance.

The present study, the effects of the working pressure and temperature on the performance of the PEM fuel cell were investigated numerically. To investigate the effects of the working condition on the performance of the PEM fuel cell, a three-dimensional model was developed. Three-dimensional single-cell was modelled with FLUENT 6.3 software by utilizing a PEMFC module. After creating a model, the convergence curves were checked to examine the accuracy of the model. Also, the independence of the solution from the number of mesh elements was examined by using five different mesh structures. The model was confirmed with the experimental data that the Wang et al. [13] had published. After verifying the model, analyses were performed for the various temperature and operating pressure values. Consequently, to assess the effects of the working pressure and temperature on the performance of the PEM fuel cell, the polarization (voltage) and power curves, the distribution of the current density that is in the form of the counter line graphics, the current density curves according to pressure and temperature were given and evaluated systematically.

\section{NUMERICAL MODEL}

To investigate the working conditions on the performance of PEMFC, three-dimensional single-cells were modelled. A cross-sectional view of the PEMFC is shown in Figure 1 and dimensions of the cell are given Table 1. In this study, three-dimensional single-cell was modelled with FLUENT 6.3 software by utilizing a PEMFC module. The assumptions made in improving the model are as follows:

- The fuel cell operates under steady state condition.

- $\quad$ Flow is laminar.

- Membrane, gas diffusion layer and catalyst layer are treated as isotropic porous media.

- $\quad$ Reactant gases are regarded as ideal gases.

- Water is only in the vapour phase.

The governing equations of mass conservation, momentum conservation, energy conservation, species concentration, proton transport and electron transport are as follows:

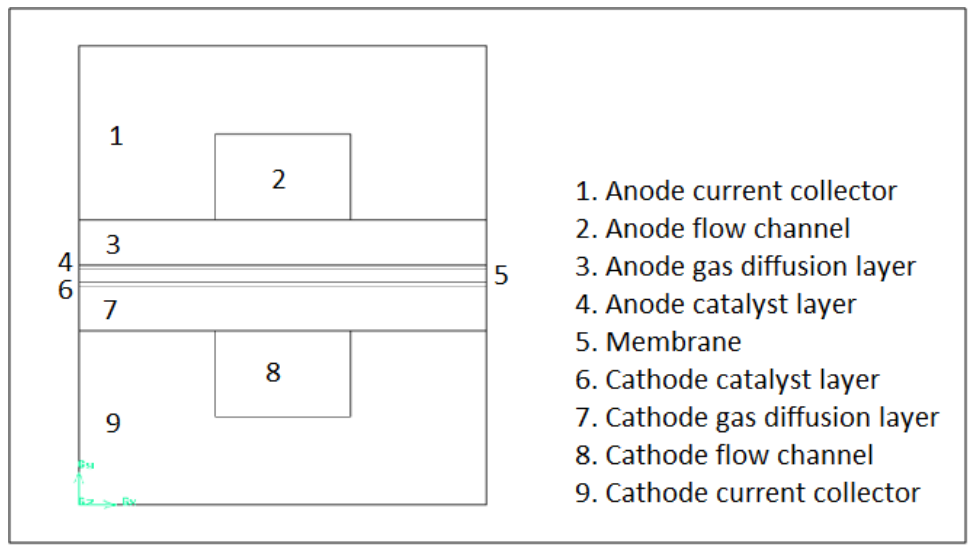

Figure 1. A cross-sectional view of the PEMFC

Table 1. Geometrical parameters of the fuel cell model

\begin{tabular}{|l|c|}
\hline Parameter & MEC-1 \\
\hline Channel length $(\mathrm{mm})$ & 50 \\
\hline Channel height $(\mathrm{mm})$ & 1 \\
\hline Channel width $(\mathrm{mm})$ & 1 \\
\hline Current collector width $(\mathrm{mm})$ & 3 \\
\hline Current collector height $(\mathrm{mm})$ & 2 \\
\hline Gas diffusion layers thickness $(\mathrm{mm})$ & 0.3 \\
\hline Catalyst layers thickness $(\mathrm{mm})$ & 0.01 \\
\hline Membrane thickness $(\mathrm{mm})$ & 0.05 \\
\hline
\end{tabular}


- Mass conservation equation

$$
\nabla \cdot(\varepsilon \rho \vec{u})=0
$$

- Momentum conservation equation

$$
\nabla \cdot(\varepsilon \rho \vec{u} \vec{u})=-\varepsilon \nabla p+\nabla \cdot(\varepsilon \mu \nabla \vec{u})+S_{u}
$$

In the momentum conservation equation, $S_{u}$ are external body forces and presented in Table 2 .

- Energy conservation equation

$$
\nabla \cdot(\varepsilon \rho \vec{u} h)=\nabla \cdot(k \nabla T)+S_{h}
$$

Where, $h$ is the enthalpy, $k$ is the thermal conductivity and $S_{h}$ is the energy source term and is defined in Table 2.

- Species concentration equation

$$
\nabla \cdot\left(\varepsilon \vec{u} C_{k}\right)=\nabla \cdot\left(D_{k}^{e f f} \nabla C_{k}\right)+S_{k}
$$

In Equation 4, $S_{k}$ is the source term and is given Table 2, $D_{k}^{\text {eff }}$ is the effective gas species diffusivity and can be expressed as:

$$
D_{k}^{e f f}=\varepsilon^{1.5} D_{k}
$$

- Proton transport and electron transport equation

$$
\begin{aligned}
& \nabla .\left(\sigma_{m} \nabla \phi_{m}\right)=S_{i} \\
& \nabla .\left(\sigma_{s} \nabla \phi_{s}\right)=S_{e}
\end{aligned}
$$

In the proton transport and electron transport equation, $\sigma_{m}$ is the ionic conductivity, $\phi_{m}$ is the membrane potential, $\sigma_{s}$ is the electrical conductivity, $\phi_{s}$ is the solid phase potential. $S_{i}$ and $S_{e}$ are the source terms of these equations and are given Table 2. Electrochemical and transport properties are listed in Table 3.

Table 2. Source terms

\begin{tabular}{|l|c|c|c|c|c|}
\hline $\begin{array}{l}\text { Component } / \\
\text { Source terms }\end{array}$ & $\begin{array}{c}S_{u} \\
\text { (Momentum) }\end{array}$ & $S_{h}($ Energy) & $S_{k}$ (Species) & $\begin{array}{c}S_{e} \\
\text { (Potential) }\end{array}$ & $\begin{array}{c}S_{i} \\
\text { (Potential) }\end{array}$ \\
\hline $\begin{array}{l}\text { Current } \\
\text { collectors }\end{array}$ & 0 & 0 & 0 & 0 & 0 \\
\hline Gas channels & 0 & 0 & 0 & 0 & 0 \\
\hline $\begin{array}{l}\text { Gas diffusion } \\
\text { layers }\end{array}$ & $-\frac{\mu}{K} \varepsilon^{2} \vec{u}$ & 0 & 0 & 0 & 0 \\
\hline Catalyst layer & $-\frac{\mu}{K} \varepsilon^{2} \vec{u}$ & $h_{\text {reaction }}+j_{a c .} \cdot \eta_{a . c}+\frac{i_{s}^{2}}{\sigma_{s}^{e f f}}+\frac{i_{m}^{2}}{\sigma_{m}^{e f f}}+h_{\text {phase }}$ & $\begin{array}{l}H_{2}:-\frac{M_{H_{2}}}{2 F} j_{a} \\
O_{2}:-\frac{M_{O_{2}}}{4 F} j_{c} \\
H_{2} O: \frac{M_{H_{2} O}}{2 F} j_{c}+\frac{n_{d} M_{H_{2} O}}{2 F} j_{c}\end{array}$ & $j$ & $j$ \\
\hline Membrane & $-\frac{\mu}{K} \varepsilon^{2} \vec{u}$ & 0 & 0 & 0 & 0 \\
\hline
\end{tabular}


Table 3. Electro chemical and transport properties

\begin{tabular}{|l|l|}
\hline Parameter [Units] & Value \\
\hline Anode reference current density $\left[\mathrm{A} . \mathrm{m}^{-3}\right]$ & $1.5 \times 10^{9}$ \\
\hline Anode reference molar concentration[kmol.m & -1 \\
\hline Anode concentration exponent & 0.5 \\
\hline Anode transfer coefficient & 2 \\
\hline Anode backing layer porosity & 0.4 \\
\hline Cathode reference current density $\left[\mathrm{A} . \mathrm{m}^{-3}\right]$ & $4 \times 10^{6}$ \\
\hline Cathode reference molar concentration & 1 \\
\hline Cathode concentration exponent & 1 \\
\hline Cathode transfer coefficient & 2 \\
\hline Cathode backing layer porosity & 0.4 \\
\hline Open-circuit voltage [V] & 0.95 \\
\hline Reference diffusivity of hydrogen $\left[\mathrm{m}^{2} . \mathrm{s}^{-1}\right]$ & $9.15 \times 10^{-5}$ \\
\hline Reference diffusivity of oxygen $\left[\mathrm{m}^{2} . \mathrm{s}^{-1}\right]$ & $2.2 \times 10^{-5}$ \\
\hline Reference diffusivity of water vapour $\left[\mathrm{m}^{2} . \mathrm{s}^{-1}\right]$ & $2.56 \times 10^{-5}$ \\
\hline
\end{tabular}

\section{Boundary and Operating Condition}

Boundary conditions have to be defined to solve the discretized equation. At the inlet of the gas flow channels, the mass flow inlet boundary conditions are defined as a boundary condition. Flow rate, temperature, and spices concentrations are described as the inlet values at the flow channels. Well-humidified hydrogen enters the anode side flow channel and well-humidified air enters the cathode side flow channel. The values of mass flow rates of air and hydrogen are $4.68 \times 10^{-5} \mathrm{~kg} \cdot \mathrm{s}^{-1}$ and $1.762 \times 10^{-6} \mathrm{~kg} \cdot \mathrm{s}^{-1}$, respectively. At the outlet of the gas flow channels, pressure outlet boundary conditions are used. Solution zone, except the current collector plates areas, are defined as fluid, the current collector plates are defined as a solid. Top and bottom surfaces of the cell are assumed as walls which have a constant temperature.

\section{Solution Method}

The equations were solved in the FLUENT 6.3 software which uses finite volume method to discretize equations. The solution zones were created and meshed in the GAMBIT software as shown in Figure 2. To investigate independent of grid size and balancing solution time, the solution zones were meshed in five different mesh sizes. In all calculations, the SIMPLE algorithm was used to solve the discretized equations of pressurevelocity coupling. To discretize pressure, the standard scheme was used and the first-order upwind scheme was used to discretize other equations. For all characteristics, iterations were continued until solutions converge up to $10^{-6}$.
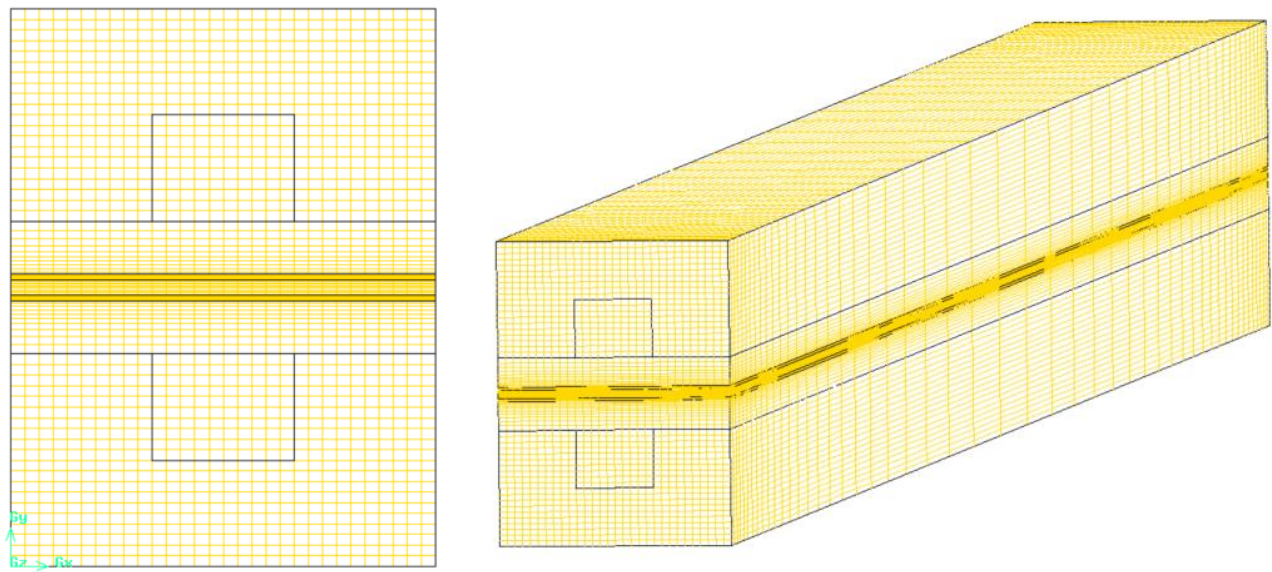

Figure 2. Mesh structure of PEMFC. 


\section{Model Validation}

In order to validate the model, the results obtained from the computations were compared with the experimental data which was taken from the study of Wang et al. [13]. Geometrical parameters of the reference study were given Table 4. To compare the model predictions and experimental results, the polarization curves were shown in Figure 3. As can be seen in Figure 3, the model results are overwhelmingly in good agreement with the experimental data from the literature [13] except for the values of current density greater than about $1.1 \mathrm{~A} / \mathrm{cm}^{2}$. The difference in this interval is probably due to the poor performance of the PEM fuel cell because of the adverse effects of water flooding which was ignored at the model.

Table 4. Geometrical parameters of the reference study [13]

\begin{tabular}{|l|c|}
\hline Parameter & MEC-1 \\
\hline Channel length $(\mathrm{mm})$ & 70 \\
\hline Channel height $(\mathrm{mm})$ & 1 \\
\hline Channel width $(\mathrm{mm})$ & 1 \\
\hline Current collector width $(\mathrm{mm})$ & 3 \\
\hline Current collector height $(\mathrm{mm})$ & 2 \\
\hline Gas diffusion layers thickness $(\mathrm{mm})$ & 0.3 \\
\hline Catalyst layers thickness $(\mathrm{mm})$ & 0.0129 \\
\hline Membrane thickness $(\mathrm{mm})$ & 0.108 \\
\hline
\end{tabular}

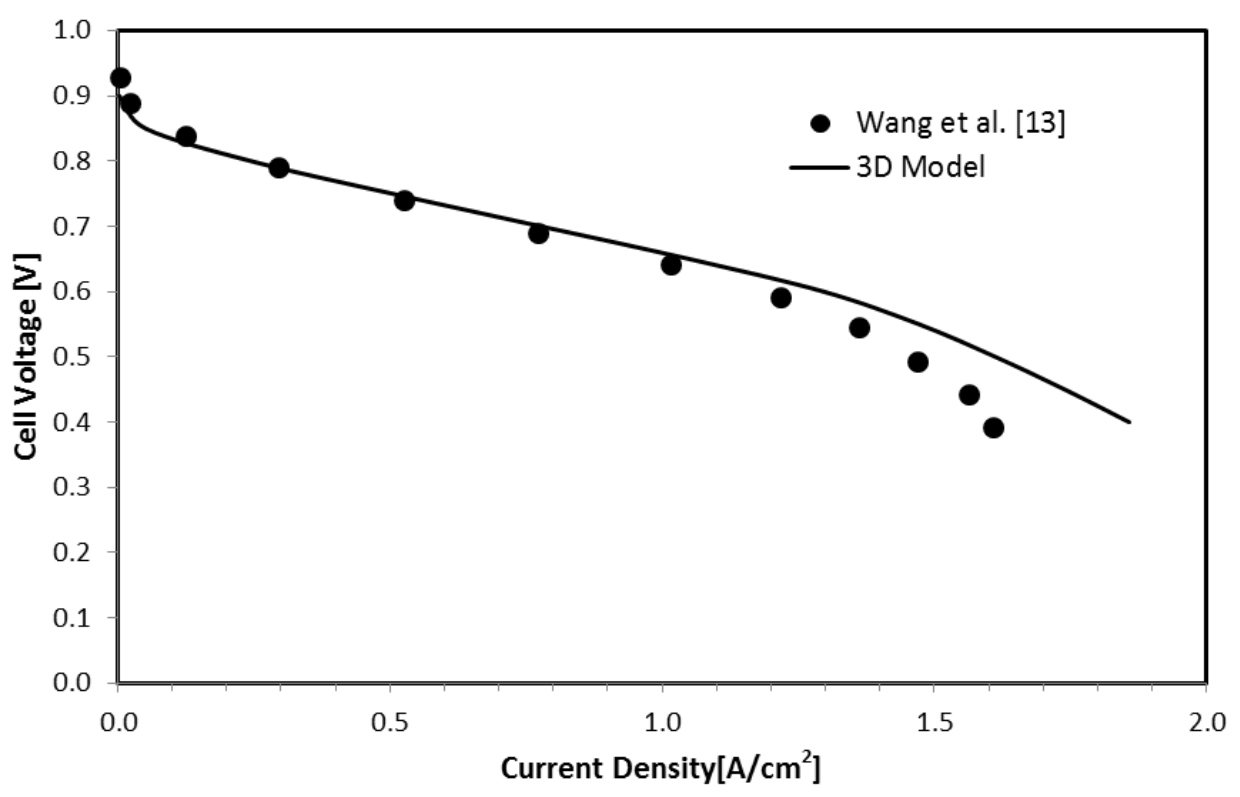

Figure 3. Comparison between the model predictions and the experimental results [13]

\section{RESULTS AND DISCUSSION}

In order to investigate the effect of operating conditions on cell performance, the analyses were performed for three different temperature and pressure values. After the analyses, the polarization (voltage) and power variations with respect to the current density are given in Figures 4-6 according to the various values of the temperature and pressure. The current density distributions were given in Figures 7 and 8 for various temperatures $(313 \mathrm{~K}, 333 \mathrm{~K}$ and $353 \mathrm{~K})$ and pressures $(100 \mathrm{kPa}, 200 \mathrm{kPa}$ and $300 \mathrm{kPa})$ in the form of contour line graphics. In addition, the current density variations with respect to temperature and pressure were given in Figures 9 and 10 .

Figure 4, Figure 5 and Figure 6 demonstrate the variations of the polarization (voltage) and power curves in the conditions of three different temperatures and operating pressures. As it can be seen in Figures 4-6, the effect of temperature is extremely clear at the values of the high current densities and it can be said that the increase of temperature increases cell voltage and cell power. Especially after the $1.1 \mathrm{~A} / \mathrm{cm}^{2}$ of the current density, these differences have become more obvious for both the polarization (voltage) and power. The results are similar for 
the three operating pressures but the effect of temperature is more pronounced at high pressures. The cell voltage and cell power increase with increasing operating pressure. At all conditions, the cell potential decreases with increasing current density; also with increasing current density, firstly, power reaches its maximum value and then decreases.

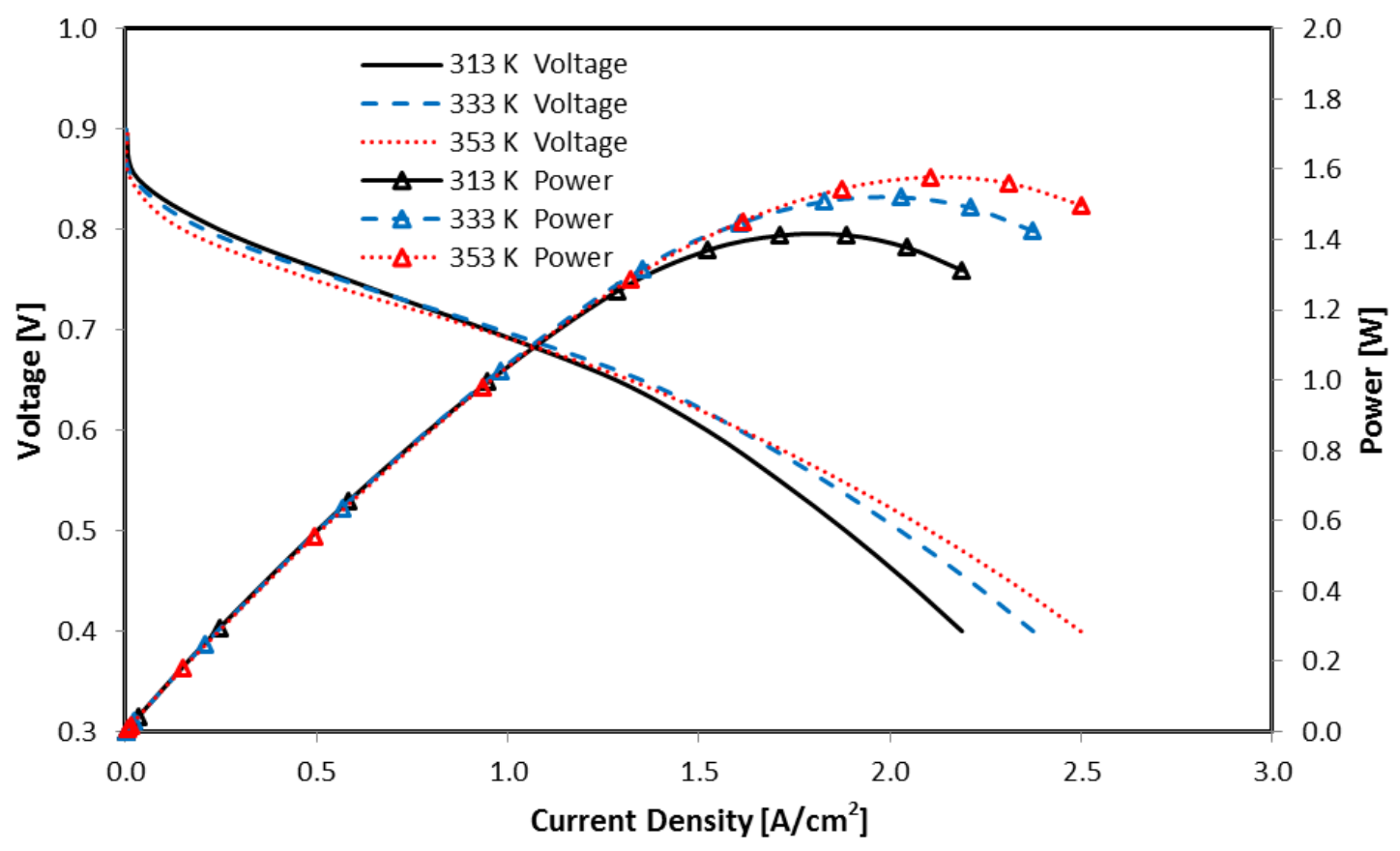

Figure 4. Effect of temperature on the cell performance for $100 \mathrm{kPa}$ operating pressure

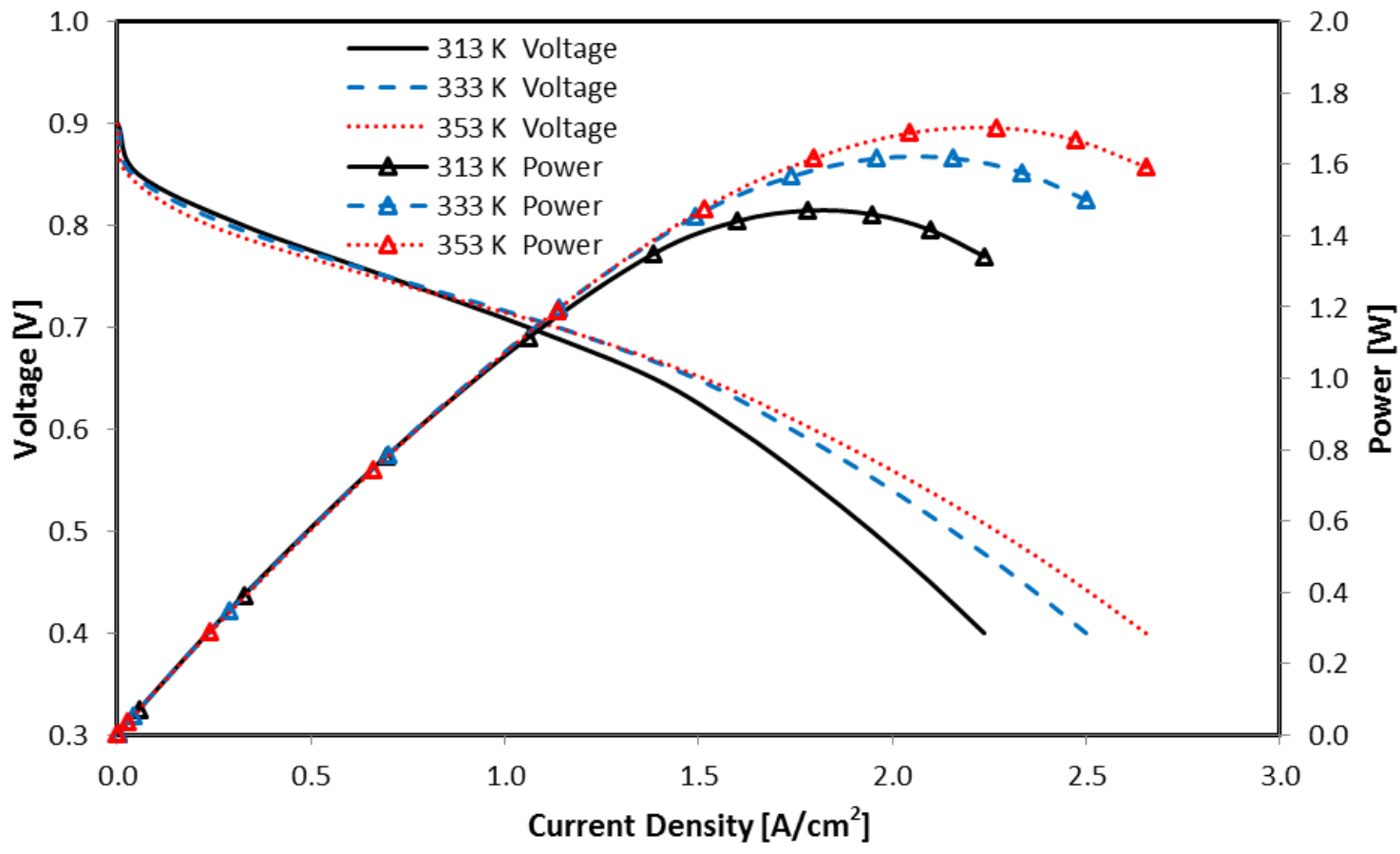

Figure 5. Effect of temperature on the cell performance for $200 \mathrm{kPa}$ operating pressure 


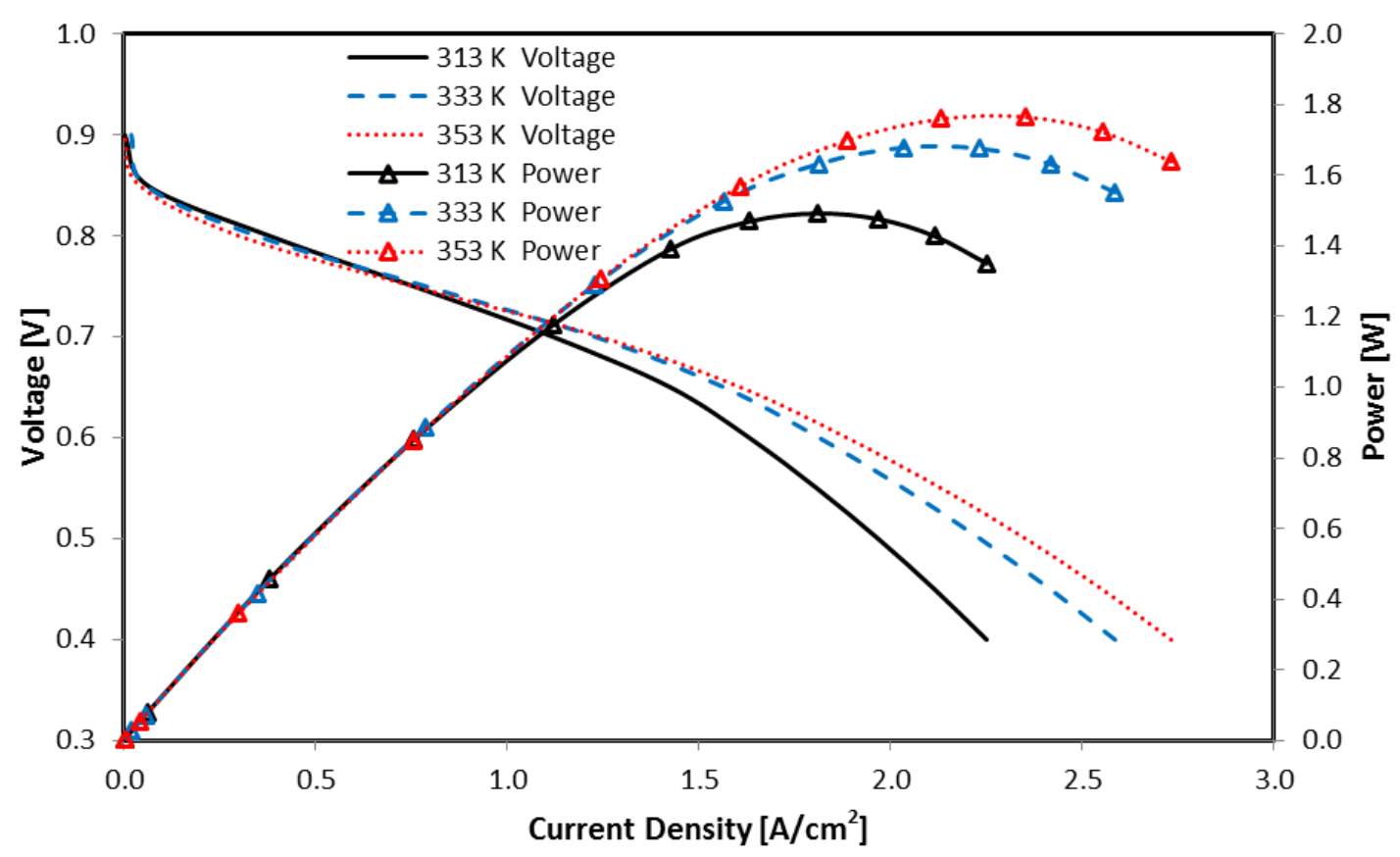

Figure 6. Effect of temperature on the cell performance for $300 \mathrm{kPa}$ operating pressure

For different temperatures, the current density distribution is given as counter graphic in Figure 7. The comparison was carried out at $300 \mathrm{kPa}$ pressure and $0.5 \mathrm{~V}$ cell potential. It is seen that increasing the temperature increases the amount of maximum current density and the nonhomogeneous distribution of the current density. The maximum current densities occur near the flow channel and the amount of current density decreases towards the outlet cross-section. Figure 8 shows the current density distribution in the form of counter line graphics for three different operating pressures. The graphics were drawn by using data obtained for a temperature of $353 \mathrm{~K}$ and a cell potential of $0.5 \mathrm{~V}$. Referring to Figure 7 and Figure 8, it can be said that the effect of pressure on current density is less than the effect of temperature.

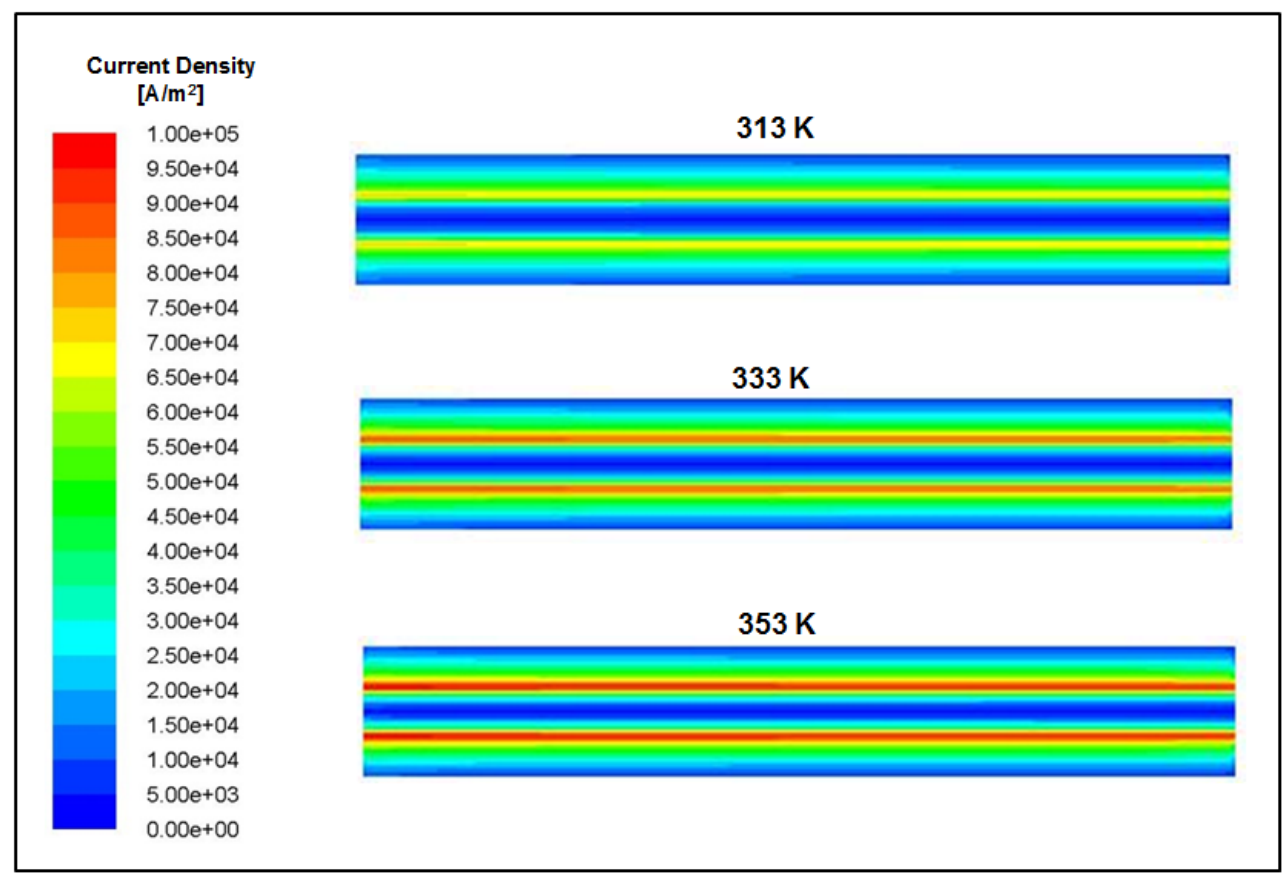

Figure 7. Current density distribution on the cross section $\mathrm{z}=2.67 \mathrm{~mm}(300 \mathrm{kPa}$ operating pressure and $0.5 \mathrm{~V}$ cell voltage) 


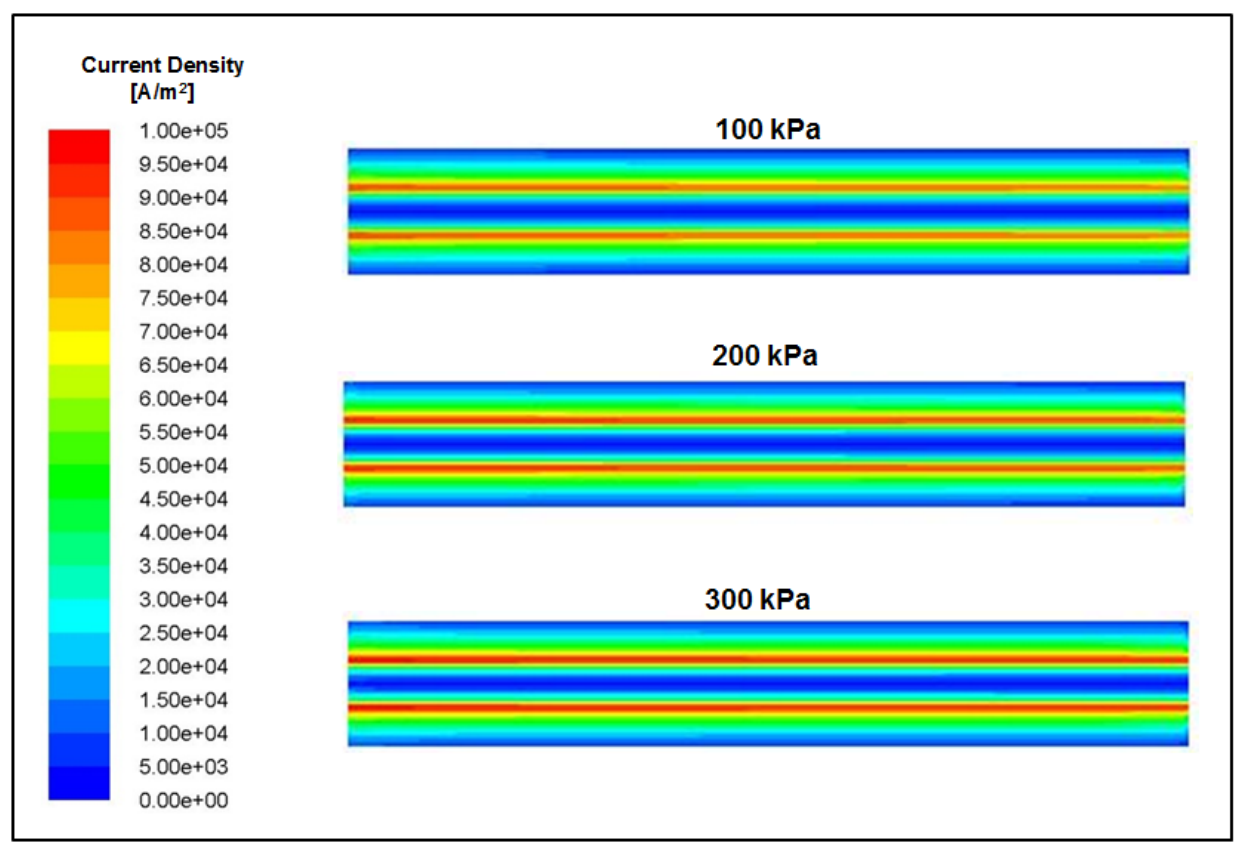

Figure 8. Current density distribution on the cross section $\mathrm{z}=2.67 \mathrm{~mm}(353 \mathrm{~K}$ temperature and $0.5 \mathrm{~V}$ cell voltage)

For $0.5 \mathrm{~V}, 0.6 \mathrm{~V}$ and $0.7 \mathrm{~V}$ cell voltages and $300 \mathrm{kPa}$ operating pressure, the current density variation with respect to the temperature were given in Figure 9. As seen in Figure 9, it can be said that the current density value increases with increasing temperature and the effect of temperature variation at low temperatures and low voltages on the current density is much more apparent. Figure 10 shows the current density change curves with respect to the pressure of 0.5, 0.6 and $0.7 \mathrm{~V}$ cell voltages for the temperature of 333K. As shown in Figure 10, the current density magnitude increases with increasing pressure and the effect of pressure variation at low pressure on current density is much more apparent. Referring to Figure 9 and Figure 10, it can be said that the effect of the temperature variation on the current density is greater than the variation of the pressure.

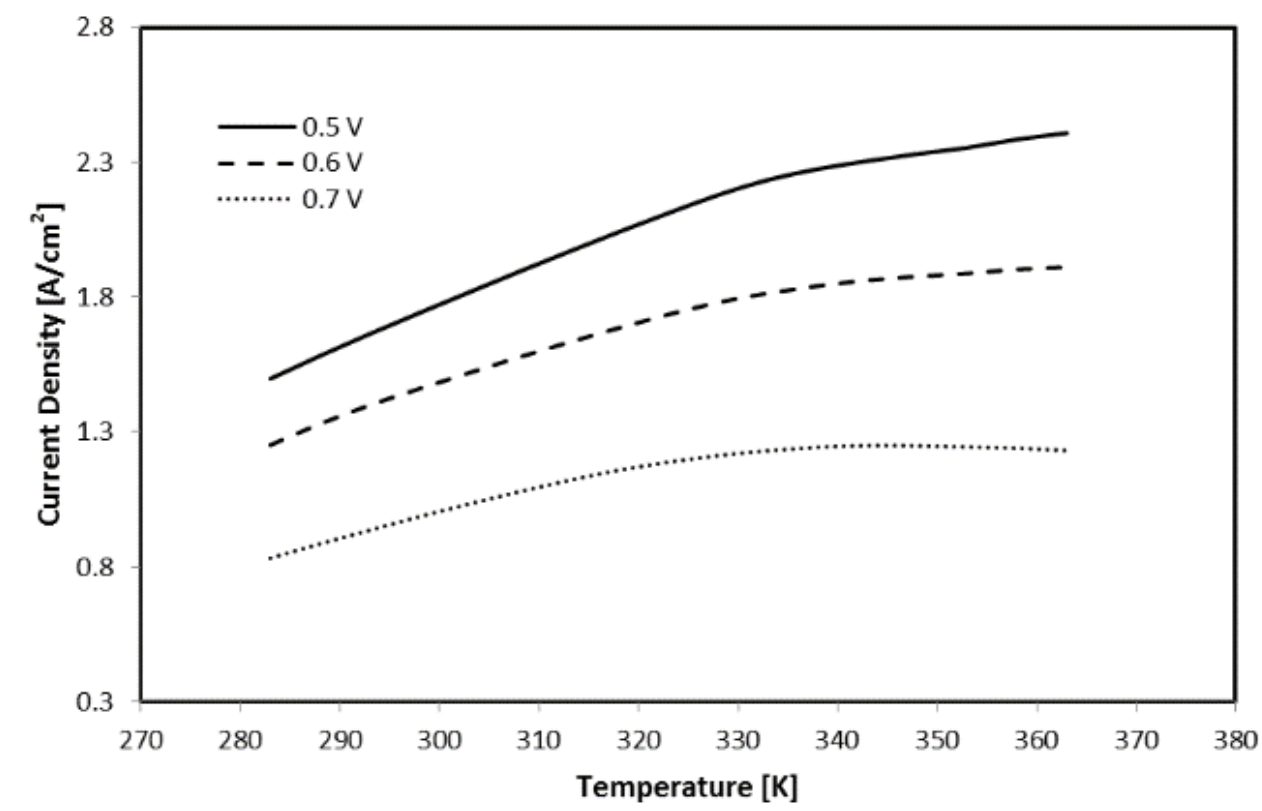

Figure 9. Effect of temperature on the PEM cell current density for different cell voltage ( $300 \mathrm{kPa}$ operating pressure) 


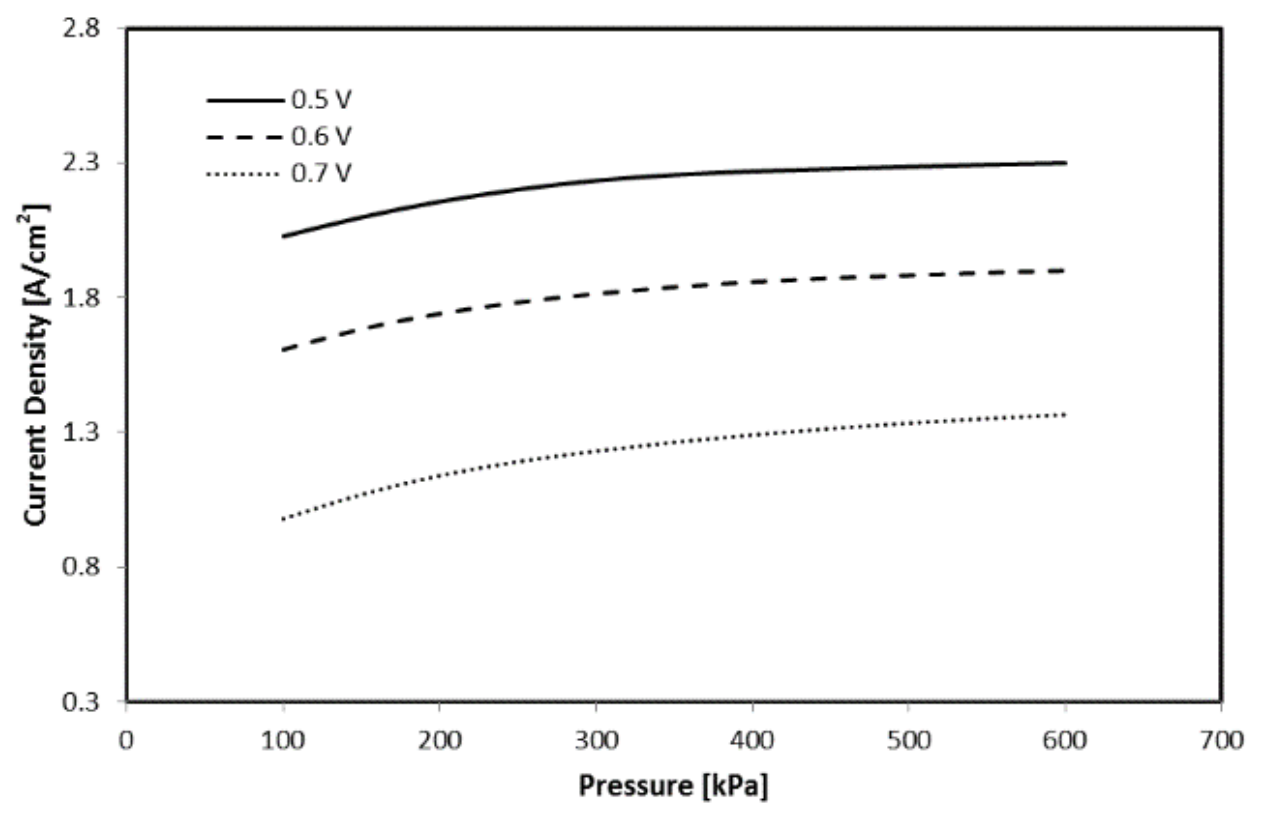

Figure 10. Effect of operating pressure on the PEM cell current density for different cell voltage ( $333 \mathrm{~K})$

Compared with similar studies in the literature, it can be concluded that the results are compatible with the literature. Yuan et al. [14], studied the effect of operating parameters on the cell performance for the PEM fuel cell with parallel flow channel structure. Their results show that, as in the current study, the increase in working pressure and working temperature increase cell performance. Besides, while increasing the current density, the effects of heat and pressure increase. With the increasing current density, the cell potential decreases and the power values increase after reaching the maximum value power values decrease. Additionally, their results showed that the effect of temperature on cell performance is more pronounced than the effect of pressure. In this study, the current density is about $2.5 \mathrm{~A} / \mathrm{cm}^{2}$ at $0.4 \mathrm{~V}$ cell potential. Yuan et al. [14], found the current density about $1.1 \mathrm{~A} / \mathrm{cm}^{2}$ at $0.4 \mathrm{~V}$ cell potential. On the other hand, Obayopo et al. [15] who have modelled the single PEM fuel cell, found the current density about $3 \mathrm{~A} / \mathrm{cm}^{2}$ at $0.4 \mathrm{~V}$ cell potential. The main reason for the different results is that the reactant flow rates were different. Also, it can be said that the design parameters are effective in different results. In general, it can be said that the results obtained in the current study and in the literature show a similar tendency.

\section{CONCLUSIONS}

In this study, a three-dimensional model was used to investigate the effects of temperature and pressure on the performance of the single PEM fuel cells. The polarization (voltage) and power variations with respect to current density, current density distributions in the form of the contour line plots and the current density variations with respect to temperature and pressure are given graphically. According to the obtained result, the cell voltage and cell power have increased with increasing temperature and the cell has shown similar performance for three different pressure values. Nevertheless, the effect of temperature on PEM fuel performance is much more pronounced at the high pressures. Consequently, by keeping humidification and cell temperatures in equilibrium, the performance of the cell improves with the increasing cell temperature and the cell voltage and cell power increase with the increasing operating pressure.

\section{NOMENCLATURE}

\section{$\varepsilon \quad$ Porosity}

$\rho$ Density $\left[\mathrm{kg} / \mathrm{m}^{3}\right]$

$\vec{u} \quad$ Velocity vector $[\mathrm{m} / \mathrm{s}]$

$p \quad$ Pressure $[\mathrm{Pa}]$

$\mu \quad$ Viscosity $[\mathrm{kg} \mathrm{m} / \mathrm{s}$ ]

$h \quad$ Enthalpy $[\mathrm{kJ} / \mathrm{kg}]$ 


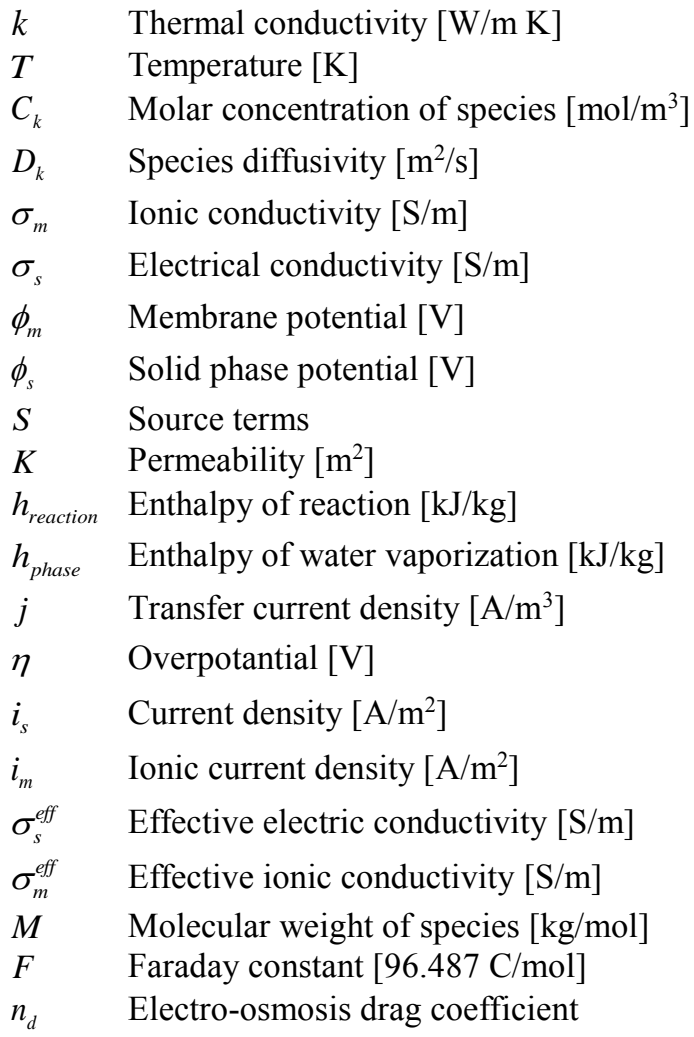

\section{REFERENCES}

[1] Sungur, B., Ozdogan, M., Topaloglu, B., Namli, L. (2017). Technical and economic evaluation of micro cogeneration systems in the context of global energy consumption (in Turkish), Engineer and Machinery, 58(686), $1-20$.

[2] Khazaee, I., Ghazikhani, M., (2012). Numerical simulation and experimental comparison of channel geometry on performance of a PEM fuel cell, Arabian Journal for Science and Engineering, 37(8), 1-13.

[3] Wang, X. D., Duan Y. Y., Yan W. M., Peng X. F. (2008). Effects of flow channel geometry on cell performance for PEM fuel cells with parallel and interdigitated flow fields, Electrochimica Acta, 53(16), 5334-5343.

[4] Güvelioğlu, G. H., Stenger, H. G. (2005). Computational fluid dynamics modeling of polymer electrolyte membrane fuel cells, Journal of Power Sources, 147, 95-106. 275-281.

[5] Kim, G., Sui, P. C., Shah, A. A., Djilali, N. (2010) Reduced-dimensional models for straight-channel proton exchange membrane fuel cells, Journal of Power Sources, 195, 3240-3249.

[6] Dadda, B., Abboudi, S., Ghezal, A. (2013) Transient two-dimensional model of heat and mass transfer in a PEM fuel cell membrane, International Journal of Hydrogen Energy, 38, 7092-7101.

[7] Berning, T., Djilali, N. (2003). Three-dimensional computational analysis of transport phenomena in a PEM fuel cell-a parametric study, Journal of Power Sources, 124, 440-452.

[8] Carcadea, E., Ene, H., Ingham, D. B., Lazar, R., Ma, L., Pourkashanian M., Stefanescu I. (2005) Numerical simulation of mass and charge transfer for a PEM fuel cell, International Communications in Heat and Mass Transfer, 32, 1273-1280.

[9] Lobato, J., Canizares P., Rodrigo, A. M., Pinar, F. J., Mena, E., Ubeda, D. (2010). Three-dimensional model of a $50 \mathrm{~cm} 2$ high-temperature PEM fuel cell. Study of the flow channel geometry influence, International Journal of Hydrogen Energy, 35, 5510-5520.

[10] Ferreira, R. B., Falcão, D. S., Oliveira, V. B., Pinto, A. M. F. (2015). A one-dimensional and two-phase flow model of a proton exchange membrane fuel cell, Journal of Chemical Technology and Biotechnology, 90(9), 1547 1551.

[11] Ahmadi, N., Dadvand, A., Rezazadeh, S., Mirzaee, I. (2016) Analysis of the operating pressure and GDL geometrical configuration effect on PEM fuel cell performance, Journal of the Brazilian Society of Mechanical Sciences and Engineering, 38(8), 2311-2325.

[12] Heidary, H., Kermani, M. J., Khajeh-Hosseini-Dalasm, N. (2016). Performance analysis of PEM fuel cells cathode catalyst layer at various operating conditions. International Journal of Hydrogen Energy, 41(47), 2227422284.

[13] Wang, L., Husar, A., Zhou T., Liu, H. (2003). A parametric study of PEM fuel cell performances, International Journal of Hydrogen Energy, 28, 1263-1277. 
[14] Yuan, W., Tang, Y., Pan, M., Li Z., Tang, B. (2010). Model prediction of effects of operating parameters on proton exchange membrane fuel cell performance, Renewable Energy, 35(3), 656-666.

[15] Obayopo, S. O., Bello-Ochende, T., Meyer, J. P. (2013). Three-dimensional optimization of a fuel gas channel of a proton exchange membrane fuel cell for maximum current density. International Journal of Energy Research, 37(3), 228-241. 